\title{
A szemészeti állapot és az életminőség kapcsolódó mérőszámai különböző korcsoportokban
}

\author{
Zeffer Tamás dr. ${ }^{1}$ - Szalay László dr. ${ }^{1}$ - Deák Klára dr. ${ }^{1}$ \\ Vass Attila dr. ${ }^{1}$ - Fejes Imre dr. ${ }^{1}$ - Czibula Ágota dr. ${ }^{2}$ \\ Zubreczki Anita dr. ${ }^{3}$. Facskó Andrea dr. ${ }^{1}$. Skribek Ákos dr. ${ }^{1}$ \\ ${ }^{1}$ Szegedi Tudományegyetem, Általános Orvostudományi Kar, Szent-Györgyi Albert Klinikai Központ, \\ Szemészeti Klinika, Szeged \\ ${ }^{2}$ Szegedi Tudományegyetem, Általános Orvostudományi Kar, Szent-Györgyi Albert Klinikai Központ, \\ Családorvosi Intézet és Rendelő, Szeged \\ ${ }^{3}$ Szegedi Tudományegyetem, Általános Orvostudományi Kar, Szent-Györgyi Albert Klinikai Központ, \\ Gyermekgyógyászati Klinika, Szeged
}

\begin{abstract}
Bevezetés: Az Egészségügyi Világszervezet adatai szerint 1,3 milliárd ember él a látásgyengeség valamilyen formájával, melynek mintegy 80\%-a megelőzhető lenne. Kutatások alátámasztják, hogy a látás csökkenése befolyásolja az életminőséget, és megrövidíti a várható élettartamot.

Célkitüzés: A Szegedi Tudományegyetem több klinikájának együttmúködésével zajló, a 40 és 80 év közötti életkorú, dél-magyarországi lakosság körében végzett felmérés (OTKA-NN-110932) szemészeti vizsgálati eredményeinek rögzítése és ezek életminőséget befolyásoló hatásainak elemzése.

Módszer: Az Országos Tudományos Kutatási Alap által finanszírozott keresztmetszeti kutatási programban összesen 731, 40 és 80 év közötti személy vett részt. A bevont 731 alanyból 717 fó (397 nő és 320 férfi) vett részt teljes körü szemészeti vizsgálaton és töltötte ki a NEI-VFQ-25 honosított kérdőívet. A statisztikai analízishez egy szempontos ANOVA- és Mann-Whitney-próbát használtunk. A szignifikancia szintjeként a p $<0,05$ értéket határoztuk meg. Eredmények: A vizsgálatban részt vevő személyeket 4 korcsoportra osztottuk: 1) 40-50 év, 2) 51-60 év, 3) 6l-70 év, 4) 71-80 év. A szemszárazság, a lencsehomályok előfordulása, a szemüvegviselés, az időskori maculadegeneratióra utaló eltérések jelenléte az életkor előrehaladtával nőtt. A NEI-VFQ-25 kérdőív alskálái az életminőség romlását mutatják a kor növekedésével és a szemészeti eltérések előfordulási gyakoriságának fokozódásával összefüggésben. Következtetés: A látás, mint a külvilág észlelésének meghatározó lehetősége, kiemelkedő helyet foglal el az életminőséget befolyásoló tényezők között. Kutatásunk tendenciái mutatják, hogy a látással kapcsolatos életminőséget jelző értékek a kor előrehaladtával hogyan csökkennek. Ezért is tekintjük szükségesnek az idősebb populáció rendszeres ellenőrzését, felismerendő és lehetőség szerint kiküszöbölendő az életminőséget negatívan befolyásoló tényezőket. Orv Hetil. 2020; 161(43): 1824-1830.
\end{abstract}

Kulcsszavak: látás, Magyarország, életminőség

\section{Ophthalmological status and its related life-quality indices in different age groups}

Introduction: According to the World Health Organization data, approximately 80\% of visual impairments, distressing 1.3 billion people, would be avoidable. A growing body of evidence supports that diminished vision influences the quality of life and shortens the expected lifetime.

Objective: To analyze the ophthalmological and life-quality data of the 40 to 80 years old South-Hungarian population in the framework of an interdisciplinary study, implemented in the University of Szeged (OTKA-NN-110932). Method: A total of 731 persons, between their 40 and 80 age years, attended for the free screening and research program, supported by the Hungarian Scientific Research Fund. The comprehensive ophthalmological examination and the adopted NEI-VFQ-25 questionnaire were passed by 717 (397 female and 320 male) participants. We applied one-way ANOVA and Mann-Whitney tests for statistical analyses. Differences were considered as statistically significant in the case of $\mathrm{p}<0.05$. 
Results: Based on their age, participants were divided into four groups: 1) 40-50 yrs, 2) 51-60 yrs, 3) 61-70 yrs, and 4) 71-80 yrs. With aging, the eyeglass-request rose, the appearance of dry eye, cataract, or age-related macular degeneration-related OCT signs increased. Subsets of the NEI-VFQ-25 questionnaire demonstrate a worsening of life-quality in relation to developing either ophthalmological anomalies or age.

Conclusion: Vision, as the sense serving the majority of our environmental perceptions, has a specific share among impacts that can influence life-quality. Our results reveal an inverse tendency between vision-related life-quality indices and age. We emphasize the importance of regular senior screenings to identify and treat preventable vision losses.

Keywords: vision, Hungary, quality of life

Zeffer T, Szalay L, Deák K, Vass A, Fejes I, Czibula Á, Zubreczki A, Facskó A, Skribek Á. [Ophthalmological status and its related life-quality indices in different age groups]. Orv Hetil. 2020; 161(43): 1824-1830.

(Beérkezett: 2020. április 17.; elfogadva: 2020. május 19.)

\section{Rövidítések}

AMD $=$ (age-related macular degeneration $)$ időskori maculadegeneratio; $\mathrm{ANOVA}=$ (analysis of variance $)$ varianciaanalízis; $\mathrm{D}=$ dioptria $; \mathrm{D}$ cyl = cilinderdioptria $\mathrm{D}$ sph $=$ szferikus diopt ria; ETDRS $=($ Early Treatment Diabetic Retinopathy Study) a diabeteses retinopathia korai kezelésének vizsgálata; LIPCOF $=$ (lid-parallel conjunctival folds) szemhéjszéllel párhuzamos kötőhártyaredők; NEI-VFQ-25 = (National Eye Institute Visual Function Questionnaire-25) az Egyesült Államok Nemzeti Szemészeti Intézetének 25 tételes látásfunkciós kérdőíve; OCT $=$ (optical coherence tomography) optikaikoherenciatomográfia; OTKA = Országos Tudományos Kutatási Alap; SZTE $=$ Szegedi Tudományegyetem $; \mathrm{WHO}=($ World Health Organization) Egészségügyi Világszervezet

A látásgyengeség, mint közegészségügyi probléma, egyre növekvő méreteket ölt a modern társadalomban, különös tekintettel az idősödő lakosságra nézve, hiszen a látáscsökkenések döntő része az 50 év felettieket érinti. $\mathrm{Az}$ Egészségügyi Világszervezet (WHO) adatai szerint 1,3 milliárd ember él a látásgyengeség valamilyen formájával, melynek mintegy 80\%-a megelőzhető lenne. A látásgyengeség világszerte vezető okai, gyakoriságuk sorrendjében: korrigálatlan refrakciós hibák, szürke hályog, időskori maculadegeneratio (AMD), glaucoma, cukorbetegség okozta szemfenéki eltérések, szaruhártyahomály és trachoma $[1,2]$.

Kutatások alátámasztják, hogy a látásgyengeség szignifikánsan befolyásolja az életminőséget, megrövidítve a várható élettartamot [3-5]. Ezen betegeknél a mortalitás még enyhe fokú látásgyengeség esetén is több mint kétszeres a hasonló korú, nem érintett populáció tagjaihoz képest [6].

A kutatásunk részét képező szemészeti állapotfelmérés során az általános szemészeti status felmérése mellett több, az életkor előrehaladtával jellemzően megjelenő, degeneratív jellegú eltérést vizsgáltunk, amelyek hatással lehetnek a páciensek életminőségére.

A jelen felmérés célja a Szegedi Tudományegyetem (SZTE) több klinikájának együtttmúköódésével zajló, 40 és 80 év közötti, dél-magyarországi lakosság körében végzett felmérés (OTKA-NN-110932) szemészeti vizsgálati eredményeinek értékelése és az életminőség ezzel összefüggő változásainak elemzése volt.

\section{Módszer}

\section{A vizsgálati résztvevők beválogatása}

Az Országos Tudományos Kutatási Alap (OTKA) által finanszírozott, CSR/039/01825-9/2014. ügyiratszámú, a Csongrád Megyei Kormányhivatal Népegészségügyi Szakigazgatási Szerve által jóváhagyott etikai engedély alapján történő, ingyenes szürési-kutatási programban 2014. február és 2018. március között a Központi Statisztikai Hivatal népesség-nyilvántartó adatbázisából randomizált módon kiválasztott és a vizsgálatba bevont 800, 40 és 80 év közötti, Csongrád megyei lakos közül 731 (404 nő és 327 férfi) vett részt.

A vizsgálati adatok rögzítése anonim módon, számkódos betegazonosító jelöléssel történt, az adatok feldolgozását pedig az OTKA DataCenter programjával végeztük.

\section{Szemészeti vizsgálatok}

A jelen kézirat a kutatás szemészeti ágával foglalkozik. A bevont 731 fóből 717 személy (397 nő és 320 férfi) vett részt szemészeti vizsgálaton és töltötte ki a vizsgálatot követôen a szemészeti állapottal összefüggő életminőséget felmérő NEI-VFQ-25 honosított kérdőívet. A kérdő́iv 26 kérdést tesz fel, melyekből 25 a látásélményre és 1 az egészségérzetre vonatkozik. A látásminőséget 1 , a szemfájdalmat 2 , a közeli látáshoz kötött tevékenységeket 3, a távoli látáshoz kötött tevékenységeket 3 , a társadalmi funkciókat 2 , a mentális egészséget 4 , a teljesítóképességet 2 , a látásminőség alapján a környezettől való függést, illetve függetlenséget 3 , a jármúvezetést 3 , a színlátást 1 és a perifériás látást 1 kérdés alapján próbálja felmérni a kérdő́iv a kitöltés időpontjában. A kitöltés során a vizsgálatban részt vevők $1-3,1-5$, illetve $1-6$ 
közötti skálán értékelték állapotukat a vizsgált kérdésre vonatkozóan. Minél magasabb az adott kérdésre kapott pontszám, annál rosszabb a páciensnek a kérdésre vonatkozó aktuális érzete. Az így kapott értékek egységesítése céljából a kérdőív az értékeket standardizálva 0 és 100 pont között értékeli a válaszokat annak megfelelően, hogy az előző skálán kapott magasabb pontszámok a 0-hoz közeli, az alacsonyabb pontszámok a 100-hoz közeli végső értéknek feleljenek meg. Tehát ez utóbbi index magasabb értékei jobb életminőség-érzetet jelentenek.

A szemészeti vizsgálatokon részt nem vevő 14 páciensből 2 fő a beválogatási és a vizsgálati idő között elszenvedett stroke, 1 fö gerincmútét utáni mozgáskorlátozottság miatt nem jelent meg. 11 fó a kutatás ezen részében nem kívánt részt venni. A résztvevőket 4 korcsoportra osztottuk: 1. korcsoport: 40-50 év, 2. korcsoport: 51-60 év, 3. korcsoport: 6l-70 év, 4. korcsoport: 71-80 év. Az 1. csoportba 188 fó, a 2.-ba 187 fó, a 3.-ba 201 fö, a 4.-be pedig 141 fó tartozott.

A szemészeti vizsgálatokat a SZTE Szemészeti Klinikáján dolgozó orvosok és asszisztensek, a kérdőívek kitöltését pedig a felmérés anyaintézetéül szolgáló SZTE Szülészeti és Nőgyógyászati Klinikán, kutatási asszisztens felügyeletével és iránymutatásával végezték a kutatásban részt vevők.

A szemészeti anamnézis felvételét követően az automata keratorefraktométer (NIDEK [Tokió, Japán] ARK510A) eredményeit rögzítettük, majd a látóélesség meghatározása történt ETDRS- (Early Treatment Diabetic Retinopathy Study) visustábla szerint; ezután a szemnyomás mérését digitális tonométerekkel (nonkontakt és ICare [Lancashire, Egyesült Királyság] TA01 típusú), 22 Hgmm feletti érték esetén Goldmann-féle applanációs tonometriával végeztük. Ezt követően Goldmann-féle kinetikus látótérvizsgálat és biometrikus vizsgálatok (szemtengelyhosszmérés, $\mathrm{K} 1-\mathrm{K} 2$ keratometriás értékek meghatározása, elülsőcsarnok-mélység mérése) történtek Zeiss (Oberkochen, Németország) IOLMaster 500 készülékkel. A szem elülső szegmensének, valamint a szemlencsének az állapotát réslámpás (Huvitz [Szöul, Dél-Korea] HS-5000) vizsgálattal határoztuk meg. A pinguecula, pterygium, arcus senilis, corneahomály esetleges meglétét rögzítettük. A szemhéjszéllel párhuzamos kötőhártyaredők (LIPCOF - lid-parallel conjunctival folds) mértékét ugyancsak regisztráltuk [7]. A stádiumbeosztás 1-től 4-ig terjed, amelynél 1 a legkevésbé súlyos, 4 a legsúlyosabb állapotot jelenti. A szürke hályog maghomályfokozatát 0 -tól 4-ig terjedő skálán értékeltük, amelynél a 0 a lencse homálymentességét, a 4 pedig a totális lencsehomályt jelentette, a módosított Wisconsin-skála szerint [8]. A kérgi és subcapsularis homályok jelenlétét csak kvalitatíven jeleztük, mivel pupillatágítást nem végeztünk. A szemfenékről a réslámpás megtekintés mellett OCT- (optikaikoherencia-tomográfiás) készülékkel (TOPCON [Tokió, Japán] 3D OCT-2000) $6 \times 6$ mm-es maculafelvételeket is készítettünk.
A statisztikai analízishez egy szempontos ANOVApróbát alkalmaztunk, az AMD-re utaló szemfenéki jellel rendelkezők és az ilyen eltéréssel nem rendelkezők átlagvisusértékeinek összehasonlítása kivételével, amely esetben Mann-Whitney-próbát használtunk. A szignifikancia szintjeként a p<0,05 értéket határoztuk meg.

\section{Eredmények}

A vizsgálatban részt vevők átlagéletkora 59,4 \pm 10,5 év volt. A nemek százalékos megoszlásának tekintetében $55,4 \%$ nőt és $44,6 \%$ férfit vizsgáltunk. Az 1 . korcsoportban 103 nő $(54,8 \%)$ és 85 férfi $(45,2 \%)$, a 2 . korcsoportban 108 nő $(57,8 \%)$ és 79 férfi $(42,2 \%)$, a 3 . korcsoportban 114 nő $(56,7 \%)$ és 87 férfi $(43,3 \%)$, a 4 . korcsoportban pedig 72 nő $(51,1 \%)$ és 69 férfi $(48,9 \%)$ páciens volt.

Egy távolságra történő szemüvegviselést (távoli vagy közeli) regisztráltunk az 1-4. csoportok 42,6\%, 46,6\%, 42,1\% és 33,6\%-ában, míg több távolságra (egyszerre távoli és közeli) alkalmas szemüveg viselése a csoportok 14,8\%, 37,3\%, 49,5\% és 59,1\%-ában fordult elö.

A vizsgálatban részt vevő populáción belül a szürke hályog miatt nem operált szemeket automata refraktométerrel vizsgálva az emmetropia $( \pm 0,5 \mathrm{D}$ sph $)$ előfordulása az 1-4. korcsoportokban 55,4\%, 37,2\%, 25,9\%, $22,7 \%$ volt; a refrakciós hibák közül a $-0,5$ D-t meghaladó mértékú ( $\leq 0,5 \mathrm{D},-0,75$ és $-13,75 \mathrm{D}$ között) myopia (rövidlátás) $28,0 \%, 15,2 \%, 9,0 \%, 9,9 \%$; a $0,5 \mathrm{D}$-t meghaladó ( $>0,5 \mathrm{D},+0,75$ és $+8,0 \mathrm{D}$ között) hypermetropia (túllátás) 16,4\%, 47,1\%, 59,7\%, 51,3\%; astigmia (>1,0 D cyl, 1,25 és 5,25 D cyl között) 7,5\%, 6,3\%, 11,8\%, $15,8 \%$-ban fordult elő.

A szemszárazsággal összefüggésbe hozható elváltozások (pinguecula és LIPCOF) korcsoportonkénti eloszlása tekintetében pinguecula (degeneratív kötőhártya-eltérés) jelenléte igazolódott az 1 . korcsoport 1,9\%-ában, a 2 . csoport 3,1\%-ában, a 3. csoport 5,2\%-ában és a 4. csoport 6,2\%-ában. A LIPCOF-osztályozás szerint a kötőhártyaredők száma a szemszárazság súlyosságával nő. A stádiumbeosztás 1-től 4-ig terjed, amelynél 1 a legkevésbé súlyos, 4 a legsúlyosabb állapotot jelenti. A vizsgált csoportokban ezen értékek az életkor növekedésével 1,6 $\pm 1,4,1,9 \pm 1,5,2,5 \pm 1,7,3,1 \pm 1,7$ voltak, szignifikáns $(\mathrm{p}<0,05)$ különbséget mutatva az egyes értékek között, kivéve az 1. és a 2. korcsoport összehasonlításában $(\mathrm{p}>0,05)$.

A vizsgált szemekben előforduló lencsehomályok az $1-4$. korcsoportokban $0,11 \pm 0,37,0,33 \pm 0,51,1,04 \pm$ 0,84 és 1,62 $\pm 0,94$ átlagértékeket mutattak, szignifikáns eltéréssel az egyes korcsoportok között. A szürke hályog miatt múlencse-beültetéssel operált szemek százalékos aránya az 1 . korcsoportban $0,3 \%$, a 2 . csoportban $0,5 \%$, a 3 . csoportban $5,5 \%$, a 4 . csoportban $16,1 \%$ volt.

A vizsgálatban részt vevők közül az 1 . csoportban 1,8\%-nál volt detektálható AMD-re jellemző OCT-eltérés, míg ez az arány a 2 . csoportban 7,4\%, a 3. csoport- 
$30,00 \%$

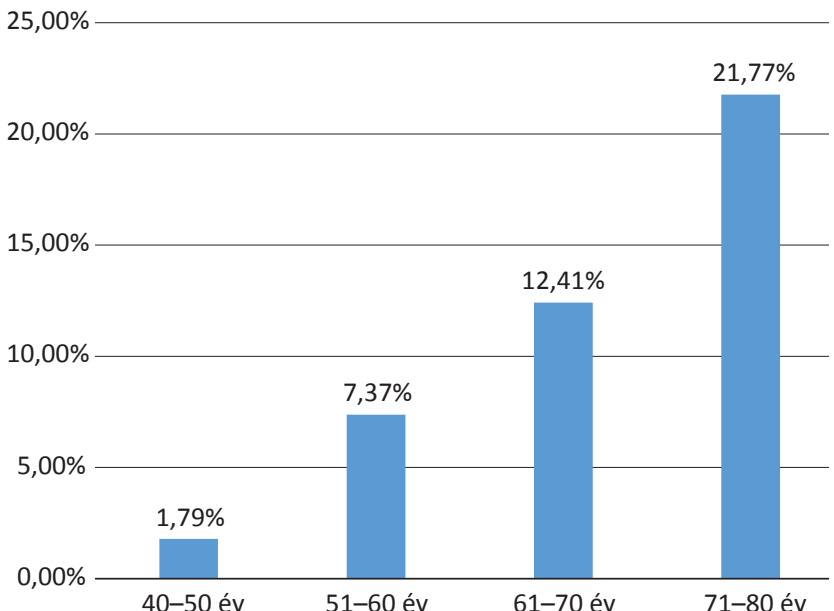

\begin{tabular}{l|l} 
1. ábra & Az AMD-re jellemző OCT-eltérésekkel rendelkező alanyok ará-
\end{tabular} nyának korcsoportonkénti megoszlása

$\mathrm{AMD}=$ időskori maculadegeneratio; $\mathrm{OCT}$ = optikaikoherenciatomográfia

ban $12,4 \%$, a 4. csoportban pedig $21,8 \%$ volt (1. ábra). A száraz típusú AMD-re utaló szemfenéki jelekkel (drusen, pigmentepithel-egyenetlenség, pigment-összecsapzódás az éleslátás helyén, a szemfenéken) rendelkező pácienseknél és az ilyen típusú eltérésekkel nem rendelkező résztvevőknél észlelt visusértékek $(0,91 \pm 0,17$ és $0,90 \pm 0,38)$ között nem tapasztaltunk szignifikáns különbséget $(\mathrm{p}=0,982)$.

A NEI-VFQ-25 kérdőív több, randomizált klinikai vizsgálatban is bizonyította megbízhatóságát [9]. A kérdőív alapján az alskálákra kapott értékeket a diagramok mutatják (2. ábra), korcsoportonkénti megoszlásban (a pontszámítást lásd a Módszer fejezetben). Az általános egészségérzet (1. csoport: $55,32,2$. csoport: 46,11 , 3. csoport: $41,79,4$. csoport: 36,35$)$ és a szubjektív látásérzet (1. csoport: $77,23,2$. csoport: $74,72,3$. csoport: $71,57,4$. csoport: 68,79$)$ a kor előrehaladtával csökkenő tendenciát mutatott (3. és 4. ábra). Az általános egészségérzet esetében a korcsoportok egymással történő összevetésekor minden esetben szignifikáns különbséget $(p<0,05)$ tapasztaltunk, kivéve a 2. és a 3. csoport között. A korcsoportok szubjektív látásminőség-érzetének összehasonlításakor az 1 . és a 3., az 1 . és a 4 ., valamint a 2. és a 4. csoport között találtunk szignifikáns különbséget $(\mathrm{p}<0,05)$.

A szemtáji fájdalomérzet hiányát jelző korcsoportonkénti átlageredmények 93,28, 88,73, 89,28, 85,90 voltak. Ezek korcsoportonkénti összehasonlításakor kizárólag az 1 . csoport értékei tértek el p<0,05 szignifikanciaértékkel a többi csoport értékeitől.

A közeli látást igénylő tevékenységek elvégzésére való képesség az 1-4. korcsoportokban átlagban 93,31,

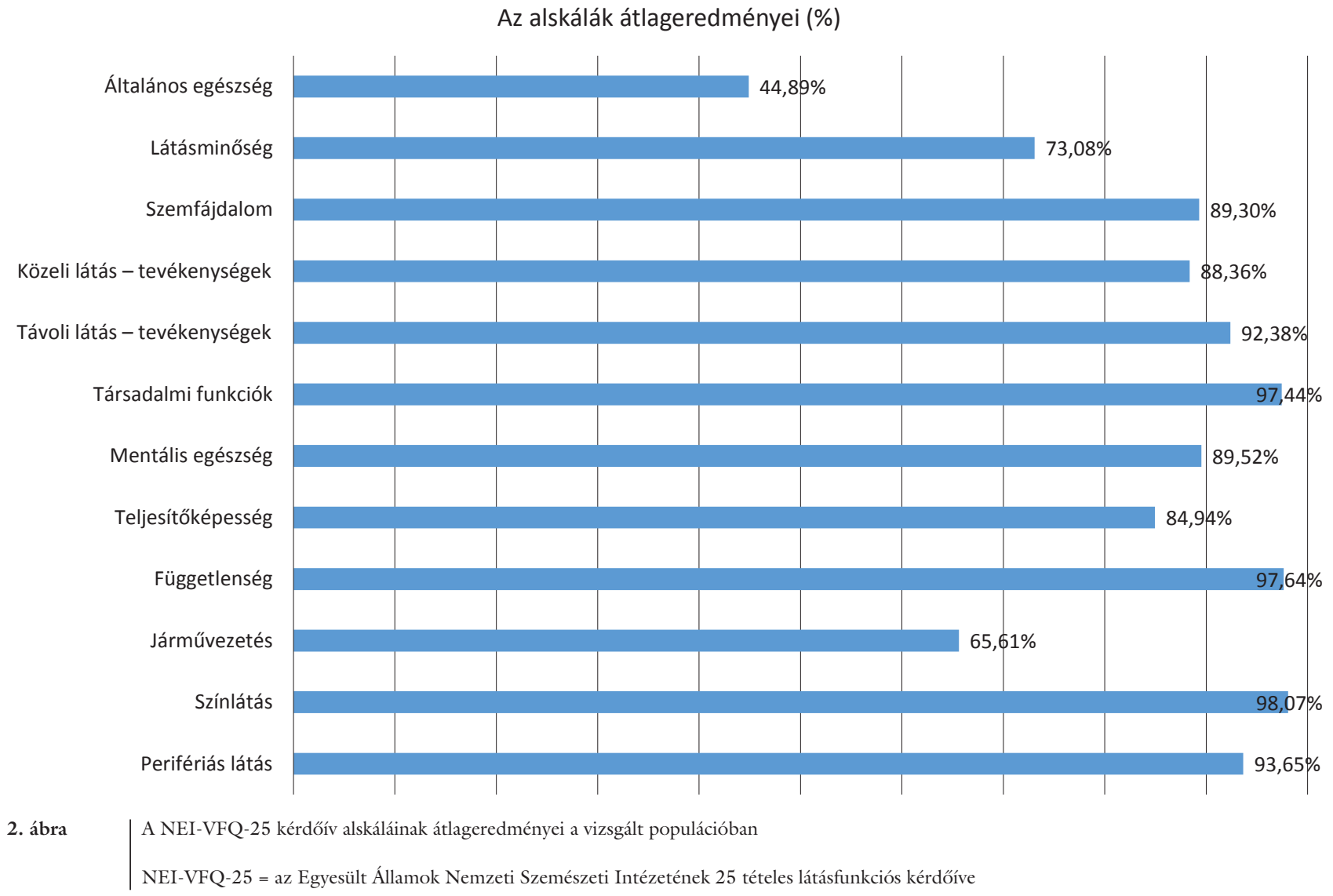




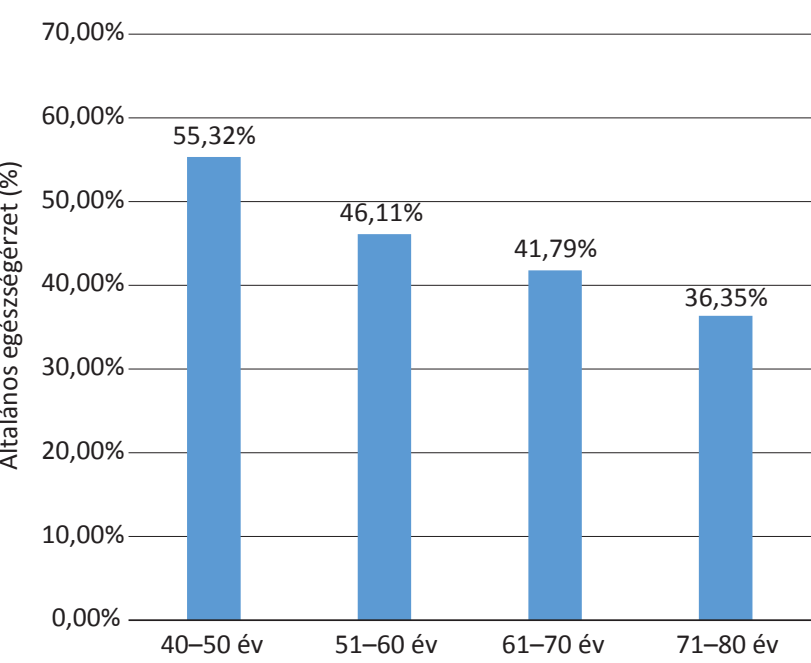

3. ábra

Az általános egészségérzet százalékos megoszlása korcsoportonként

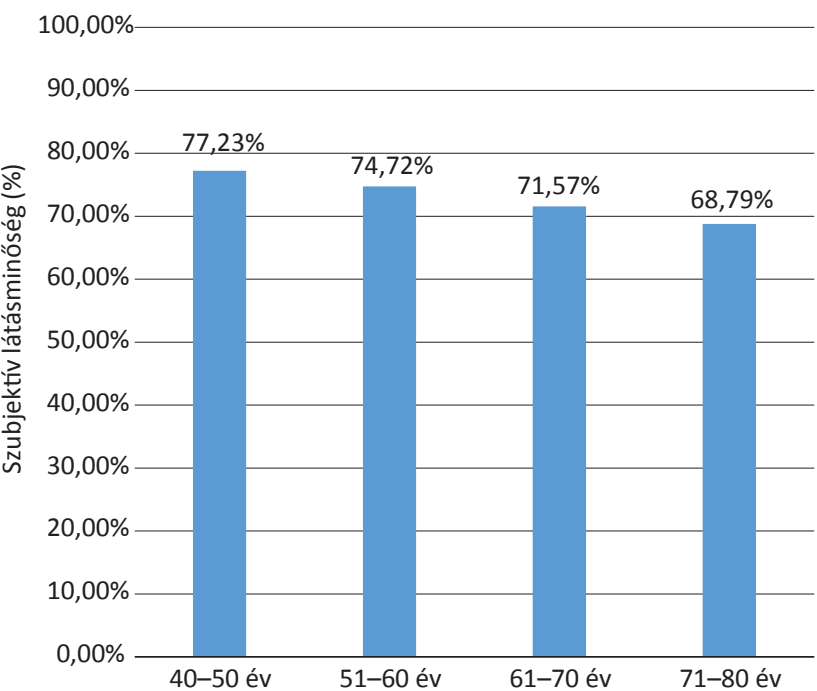

4. ábra | A látásminőség százalékos megoszlása korcsoportonként

$86,57,87,91$ és 85,67 , míg a távoli látást igénylő tevékenységeknél 95,52, 92,83, 92,38 és 88,77 volt. Az elóbbi esetében korcsoportos összehasonlításkor szignifikáns különbség $(\mathrm{p}<0,05)$ az 1 . és a $3-4$. csoportok között, míg az utóbbi esetében az l. és a 3., az l. és a 4., valamint a 2. és a 4. csoport között volt megfigyelhető.

A társadalmi funkció betöltése és a mentális egészség érzete az 1-4. korcsoportokban 99,53, 97,22, 97,43 és 95,57 , illetve a társadalmi funkciók betöltése esetében $91,92,89,55,89,98$ és 86,61 volt. Mind a társadalmi funkciók betöltése, mind a mentális egészség érzete az 1 . és a 4. csoport értékei között mutatott szignifikáns különbséget $(\mathrm{p}<0,05)$.

A színlátás érzetére vonatkozóan az egyes korcsoportok átlagos mutatói 99,73, 97,41, 97,43 és 97,7 voltak. A perifériás látásérzet tekintetében 96,41, 94,82, 93,38 és 90 pontot kaptunk eredményül. Ezen alskáláknál a korcsoportok egymással történő összehasonlítása nem mutatott szignifikáns eltérést $(\mathrm{p}>0,05)$.

A kérdőív kitér a jármúvezetési képességekre. A vizsgált populáció tagjainak $63,7 \%$-a rendszeres gépjármúvezetésről számolt be a kérdőív kitöltésekor. A felmérésben szereplők 15,5\%-a hagyta abba az autóvezetést, 2,6\%-uk látásromlás miatt, a többiek egyéb, meg nem nevezett okok miatt.

\section{Megbeszélés}

A SZTE több klinikáján végzett, az OTKA által finanszírozott kutatás célja a dél-magyarországi populáció egészségi állapotának mind szubjektív, mind objektív szemszögből történő felmérése, a kapott eredmények alapján egyszerú és könnyen kivitelezhető prevenciós javaslatok megfogalmazása volt. Az életkor hatását vizsgálandó, 4 korcsoportba osztott, 40 és 80 év közötti nők és férfiak szemészeti vizsgálatát és a szemészeti statushoz kapcsolódó életminőség felmérését végeztük, a kapott eredményeket elemeztük.

A távoli látást igénylő tevékenységek elvégzésére való képesség a korral csökkenő tendenciát mutat, bár a 2. és a 3. korcsoportban a csökkenés megtorpanni látszik. A közel azonos mutatók azt sugallják, hogy életünk ezen 20 éves periódusában stagnál a távoli tárgyakra való fókuszálás képessége, a csökkenés inkább két fázisban zajlik: az 1. és a 2., valamint a 3. és a 4. korcsoport határán.

A vizsgálatban részt vevők közeli látóképességére adott pontszámok alapján is látható a kor előrehaladtával párhuzamos csökkenés. Az 50 év feletti korcsoportoknál elsősorban stagnálást figyelhetünk meg ezen az alskálán; mindegyik korcsoportban 86 pont körüli értékeket találtunk, ami a presbyopia (öregszemúség) párhuzamos stagnálásával magyarázható 50 év felett [10].

A szemüvegviselés korcsoportonkénti megoszlását vizsgálva elmondhatjuk, hogy a Csongrád megyei lakosság a kor előrehaladtával egyre nagyobb mértékben visel szemüveget, és elsősorban a többfókuszú szemüveglencsék használata nő.

A színlátás érzete, melyet leginkább a szürke hályog jelenléte befolyásol, mind a 4 korcsoport tekintetében csak kismértékủ csökkenést mutatott, így valószínúsíthetjük, hogy az általunk vizsgált populációban a lencsehomállyal rendelkező személyek nem élték meg a lencseeltérés színlátást módosító hatását. Hasonló pontszámokat mutatott a perifériás látásérzetet vizsgáló alskála.

Felmérésünk alapján a vizsgált populáció a korcsoportonkénti lencsehomály mértékének szignifikáns növekedésével illeszkedik a szürke hályog korral növekvő prevalenciájának képébe. Hasonlóképpen, az irodalmi adatokkal összhangban, növekvő tendenciát mutat a kor előrehaladtával a múlencse-beültetettek százalékos aránya $[11]$. 
Ugyanakkor kiemelendő, hogy a látóélességet nagyobb mértékben károsító, nedves típusú AMD jelei csupán 11 résztvevő szemfenéki képén voltak megfigyelhetők, míg a páciensek döntő többségében kezdeti stádiumú, száraz típusú AMD-re utaló jeleket diagnosztizáltunk. Mindez magyarázatul szolgál az AMD-re utaló szemfenéki képpel rendelkező és az ilyen elváltozás nélküli páciensek közel azonos visusértékeire is.

A száraz szembetegség kialakulását is előrevetíti mind a LIPCOF értékének, mind a pinguecula gyakoriságának életkorral párhuzamos növekedése. Habár a szemszárazság banális problémának tûnhet, látászavar és/vagy fájdalom képében jelentkező, a páciensek által gyakran bizonytalanul leírt tünetei az életminőséget jelentősen rontani képes tényezők lehetnek!

A járművezetés képességére vonatkozó százalékos adatokat tekintve megfigyelhető, hogy míg az első 2 korcsoportban 70 feletti eredményeket látunk, a 3. és a 4. korcsoporthoz érve az értékek hirtelen lecsökkennek (59,9 és 53,0\%) (5. ábra). Mivel a vezetői engedélyhez szükséges alkalmasság a szemészeti állapoton túl egyéb szempontokat is figyelembe vesz, a jármúvezetés képességének értékelésében nyilvánvalóan ezen nem szemészeti tényezők is szerepet játszanak.

A társadalmi funkciók betöltésére és a vizsgált minta mentális egészségére vonatkozó mutatók mindegyik korcsoportban közel azonosak. A jellemzően 85 feletti értékek a vizsgált lakosság látás által lehetővé tett társadalmi szerepeirôl és kielégítő mentális egészségéről árulkodnak. A mintavételezés jellegéből fakadó óhatatlan torzító hatás mellett feltételezhetően ennek és a minden korcsoport esetében 80-at meghaladó teljesítóképességnek is köszönhetők a másoktól való függetlenség alskálájára kapott, 100-at megközelítő értékek, ami Magyarország társadalmának idősödő jellegét figyelembe véve pozitív megítéléssel bír.

\section{$100,00 \%$}

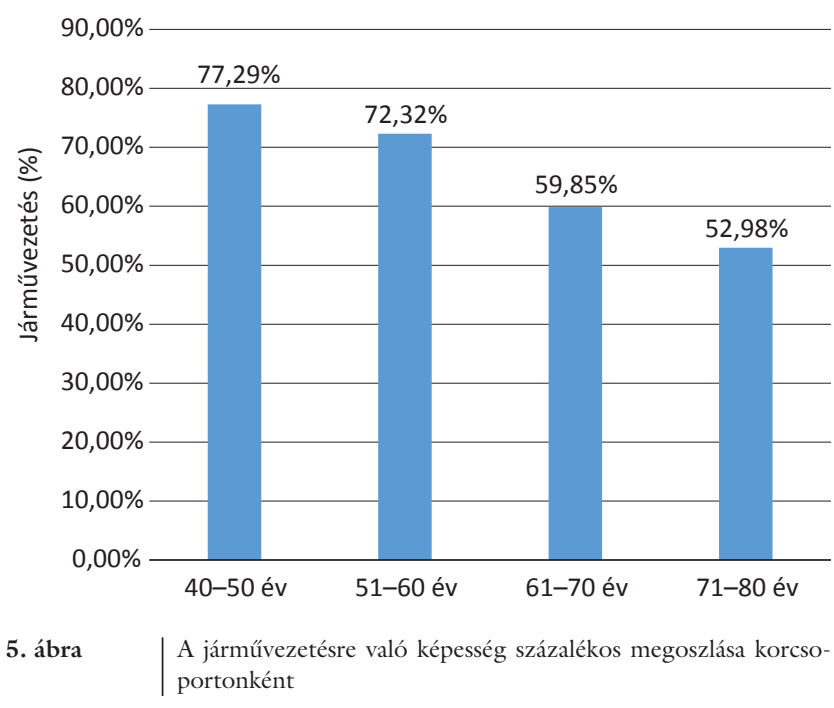

A NEI-VFQ-25 kérdőív széles körü nemzetközi alkalmazásának köszönhetően rendelkezésre állnak hasonló norvég, olasz és török vizsgálatok eredményei is [1214]. A kutatásokban az általunk tapasztalt nemi megoszláshoz (nők: $55,4 \%$ ) hasonlóan a nők részvételi aránya magasabb volt a norvég és az olasz tanulmányban $(73 \%$ és 66\%), míg a török tanulmányban a nők részvételi aránya $45,9 \%$ volt. Az átlagéletkor a norvég tanulmányban $81,7 \pm 7,5$ év, míg az olasz és a török vizsgálatban 60,6 $\pm 16,6$, illetve $60,9 \pm 14,5$ év volt. Látható, hogy ezen utóbbi két kutatás az életkor tekintetében jól összevethető a jelen vizsgálatunkban szereplő átlagéletkorral $(59,4$ $\pm 10,5$ év). Az általunk kapott életminőség-indexek a vizsgálatok nagy részében magasabb értéket mutattak, mint a fent nevezett országokban végzett kutatások átlageredményei. A különbségek okai az eltérő egészségügyi és szociokulturális állapotok miatt nehezen azonosíthatók, ám feltételezzük, hogy a norvég eredmények összevetésében a hazai magasabb életminőség-index hátterében az alacsonyabb átlagéletkor valószínúsíthető.

Eredményeinket összefoglalva elmondható, hogy a megkérdezettek közül a minél idősebb korcsoporthoz tartozók alacsonyabb pontszámmal értékelték az adott feladatkörök ellátására való képességeiket, vagyis az életkor növekedésével a látáshoz köthető, életminőséget befolyásoló tényezők negatív hatása egyre inkább előtérbe kerül.

Az általános egészségérzetnek a kor előrehaladtával mérhető csökkenése az öregedés fiziológiáját figyelembe véve magától értetődőnek mondható. Ugyanakkor hangsúlyoznunk kell, hogy a magyar társadalom általános egészségérzetére és ebből adódóan életminőségére nézve a szemészeti tényezók mellett a cukorbetegségnek, a depressziónak, a musculoskeletalis, cardiovascularis, allergiás, gastrointestinalis, cerebrovascularis, renalis, tumoros, illetve egyéb megbetegedéseknek is nyilvánvalóan kifejezett, további moduláló hatásuk lehet [15]. Habár ezen hatások vizsgálata jóval túlmutat kutatásunk fókuszán, figyelemre méltó, hogy hasonló, összetett hatás merül fel a szubjektív látásminőség-érzet kifejezett csökkenésének a látással kapcsolatos életminőséget vizsgáló egyéb alskálákkal való összevetésében is. Ennek oka a vizsgált tényezők kumulatív jellegében keresendő, ugyanis az individuum által megélt látásminőséget nem kizárólag egyetlen tényező befolyásolja, hanem az élet számos területén szükséges változatos látásfunkciók (közeli vagy távoli látásra való képesség, a látótér perifériáján megjelenő tárgyak vagy személyek észlelése) összessége. Feltételezésünk szerint a nagyobb mértékű látásminőség-csökkenés magyarázatául az szolgál, hogy a szubjektív látásérzet egészében könnyebben ítélhető meg, mint részleteire bontva.

A látás, mint a külvilág észlelésének meghatározó lehetősége, kiemelkedő helyet foglal el az életminőséget befolyásoló tényezők között. Kutatásunk tendenciái mutatják a látással kapcsolatos életminőséget jelző értékek korral való csökkenését. Eredményeinkből kiemelendő- 
nek tartjuk, hogy a célzott szemészeti vizsgálatok során, bár az egyes panaszok hátterében valószínúsíthető eltérés jellemzően felderítésre kerül, az egyén életminőségére jobban reflektáló teljes szemészeti állapotfelmérésre és tanácsadásra idő hiányában nem kerülhet sor. Továbbá nem hallgathatjuk el a kutatásnak a jellegéból fakadó hiányosságait sem: feltételezzük, hogy bár a résztvevók nem, életkor és lakhely szempontjából reprezentatív mintát alkotnak, ám megjelenésüket feltehetóen befolyásolta egyrészt, hogy ez számukra mekkora nehézséget okozott, másrészt az egészségi állapot megőrzésének igénye is. Valószínúsítjük tehát, hogy az egészségüket kevésbé fontosnak érző, rosszabb egészségi állapotú személyek alulreprezentáltak mintánkban. Ugyanakkor pont a vizsgálatban szereplők feltételezett, átlagosnál jobb egészségi állapota mellett mutatkozik meg az életminőség csökkenésének azon mértéke, mely az egyes, korral járó szemészeti eltérések, panaszok tekintetében talán nem is tûnik jelentősnek, ám összeadódva már kifejezett életminőség-romlást okozhat.

\section{Következtetés}

Fontosnak tartjuk a szemészeti szúrések kiterjesztését 40 év felett, bevonva az optometristákat is. A háziorvosi, illetve bármely egyéb, jellemzően idősekkel foglalkozó szakterület rendelésén dolgozó kollégáink és asszisztenseik nemcsak a betegirányításban, hanem sok esetben a tanácsadásban is jelentős támogatást nyújthatnak. Akár elrettentő példaként tekintve arra, hogy a cukorbetegeknek, mint kiemelkedő rizikócsoportba tartozóknak, alig több mint fele jár évente szemészeti szúrővizsgálatra [16], akár figyelembe véve, hogy a száraz szem okozta panaszok felfedése és javaslat nyújtása az esetek jelentôs részében tanácsadással jól megoldható, könnyen belátható, hogy a pácienseknek a szưrővizsgálatok során történő szélesebb körü elérése rendkívül fontos mind a betegségek ellátásában, mind a korral járó, életminőséget rontó változásokra adott válaszok megfogalmazásában.

\section{Anyagi támogatás: A kutatást az OTKA-NN-110932.} számú pályázat támogatta.

Szerzői munkamegosztás: F. I., V. A., D. K., Z. T.: Vizsgáló orvosok. Sz. L.: A statisztikai felelős. Cz. Á., Z. A.: Adatfeldolgozás. F. A., S. Á.: Koordinátorok. A cikk végleges változatát valamennyi szerző elolvasta és jóváhagyta.

Érdekeltségek: A szerző́knek nincsenek érdekeltségeik.

\section{Irodalom}

[1] Bourne RR, Flaxman SR, Braithwaite T, et al. Magnitude, temporal trends, and projections of the global prevalence of blindness and distance and near vision impairment: a systematic review and meta-analysis. Lancet Glob Health 2017; 5: e888-e897.

[2] Fricke TR, Tahhan N, Resnikoff S, et al. Global prevalence of presbyopia and vision impairment from uncorrected presbyopia: systematic review, meta-analysis, and modelling. Ophthalmology 2018; 125: 1492-1499.

[3] Weih LM, Hassell JB, Keeffe J. Assessment of the impact of vision impairment. Invest Ophthalmol Vis Sci. 2002; 43: 927935.

[4] Péntek M, Brodszky V, Biró Z, et al. Subjective health expectations of patients with age-related macular degeneration treated with antiVEGF drugs. BMC Geriatr. 2017; 17: 233.

[5] Ramrattan RS, Wolfs RC, Panda-Jonas S, et al. Prevalence and causes of visual field loss in the elderly and associations with impairment in daily functioning: the Rotterdam Study. Arch Ophthalmol. 2001; 119: 1788-1794. [Correction: Arch Ophthalmol. 2002; 120: 525.]

[6] McCarty CA, Nanjan MB, Taylor HR. Vision impairment predicts 5 year mortality. Br J Ophthalmol. 2001; 85: 322-326.

[7] Németh J, Fodor E, Lang Z, et al. Lid-parallel conjunctival folds (LIPCOF) and dry eye: a multicentre study. Br J Ophthalmol. 2012; 96: 1380-1385.

[8] Srivastava R, Gao X, Yin F, et al. Automatic nuclear cataract grading using image gradients. J Med Imaging (Bellingham) 2014; 1: 014502.

[9] Sivaprasad S, Tschosik E, Kapre A, et al. Reliability and construct validity of the NEI VFQ-25 in a subset of patients with geographic atrophy from the phase 2 Mahalo study. Am J Ophthalmol. 2018; 190: 1-8.

[10] Kollbaum PS, Bradley A. Correction of presbyopia: old problems with old (and new) solutions. Clin Exp Optom. 2020; 103: 2130 .

[11] Sándor GL, Tóth G, Szabó D, et al. Cataract blindness in Hungary. Int J Ophthalmol. 2020; 13: 438-444.

[12] Schippert AC, Jelin E, Moe MC, et al. The impact of age-related macular degeneration on quality of life and its association with demographic data: results from the NEI VFQ-25 Questionnaire in a Norwegian population. Gerontol Geriatr Med. 2018; 4: $1-9$.

[13] Rossi GC, Milano G, Tinelli C. The Italian version of the 25item National Eye Institute Visual Function Questionnaire: translation, validity, and reliability. J Glaucoma 2003; 12: 213220.

[14] Toprak AB, Eser E, Guler C, et al. Cross-validation of the Turkish version of the 25-item National Eye Institute Visual Functioning Questionnaire (NEI-VFQ 25). Ophthalmic Epidemiol. $2005 ; 12: 259-269$.

[15] Kollányi Zs, Imecs O. Health and life-quality. In: Kollányi Zs, Imecs $O$. The health - investment. [Egészség és életminőség. In: Kollányi Zs, Imecs O. Az egészség - befektetés.] DEMOS Magyarország - TESZ Alapítvány, Budapest, 2007; pp. 54-75. [Hungarian]

[16] Tóth G, Szabó D, Sándor GL, et al. Diabetes and diabetic retinopathy in people aged 50 years and older in Hungary. Br J Ophthalmol. 2017; 101: 965-969.

(Skribek Ákos dr., Szeged, Korányi fasor 10-11., 6720 e-mail: skribek.akos@med.u-szeged.hu)

A cikk a Creative Commons Attribution 4.0 International License (https://creativecommons.org/licenses/by/4.0/) feltételei szerint publikált Open Access közlemény, melynek szellemében a cikk bármilyen médiumban szabadon felhasználható, megosztható és újraközölhető, feltéve, hogy az eredeti szerző és a közlés helye, illetve a CC License linkje és az esetlegesen végrehajtott módosítások feltüntetésre kerülnek. (SID_1) 